\title{
High level of infection by Toxoplasma gondii in pigs slaughtered in the city of São Luís, Maranhão
}

\author{
Alto nível de infecção por Toxoplasma gondii em suínos abatidos na cidade de \\ São Luís, Maranhão
}

\begin{abstract}
Ellainy Maria Conceição Silva'; Pablo dos Santos Sousa'; Scarleth Kevia Gomes Silva de Carvalho²; Ingrid Carolinne Lopes Marques'; Francisco Borges Costa'; Andrea Pereira da Costa';

Larissa Sarmento dos Santos ${ }^{3}$; Maria do Socorro Costa Oliveira Braga ${ }^{3}$; Ana Lúcia Abreu-Silva'; Rosangela Zacarias Machado4; Alcina Vieira de Carvalho Neta1,5* (1)
\end{abstract}

\author{
'Programa de Pós-graduação em Ciência Animal, Universidade Estadual do Maranhão - UEMA, São Luís, MA, Brasil \\ ${ }^{2}$ Curso de Medicina Veterinária, Centro de Ciências Agrárias, Universidade Estadual do Maranhão - UEMA, São Luís, MA, Brasil \\ ${ }_{3}^{3}$ Programa de Pós-graduação Profissional em Defesa Sanitária Animal, Universidade Estadual do Maranhão - UEMA, São Luís, MA, Brasil \\ ${ }^{4}$ Departamento de Patologia, Reprodução e Saúde Única, Faculdade de Ciências Agrárias e Veterinárias - FCAV, \\ Universidade Estadual Paulista - UNESP, Jaboticabal, SP, Brasil \\ ${ }^{5}$ Programa de Pós-graduação Rede de Biodiversidade e Biotecnologia da Amazônia Legal, \\ Universidade Estadual do Maranhão - UEMA, São Luís, MA, Brasil
}

How to cite: Silva EMC, Sousa PS, de Carvalho SKGS, Marques ICL, Costa FB, da Costa AP, et al. High level of infection by Toxoplasma gondii in pigs slaughtered in the city of São Luís, Maranhão. Braz J Vet Parasito/ 2021; 30(4): e008721. https://doi.org/10.1590/ S1984-29612021086

\begin{abstract}
A serological, molecular and histopathological study was carried out in order to investigate occurrences of Toxoplasma gondii in pigs slaughtered with and without inspection service. Serum samples were collected from 60 pigs to detect anti-T. gondii antibody by indirect fluorescent antibody (IFAT). Tongue, masseter and diaphragm fragments were also collected for parasite DNA detection by means of the polymerase chain reaction (PCR) and histopathological analysis. The serological results showed that $77 \%(44 / 60)$ of the pigs were positive. Regarding PCR, 66.67\% (40/60) were positive for T. gondii. Among the tissues evaluated, the diaphragm was the one with the highest frequency of positivity $(40 \% ; 24 / 60)$, followed by the masseter $(38.33 \% ; 23 / 60)$ and tongue $(33.3 \% ; 20 / 60)$. Histopathological changes were only observed in the diaphragm, which presented inflammatory infiltrates of lymphohistiocytic and neutrophilic types. These results not only show the potential threat of $T$. gondii to human health, but also demonstrate the dynamic epidemiological situation of toxoplasmosis in pigs in the city of São Luís, providing support for food security regarding pigs and for T. gondii control programs in Brazil.
\end{abstract}

Keywords: Pigs, zoonosis, toxoplasmosis, public health.

\begin{abstract}
Resumo
Realizou-se um estudo sorológico, molecular e histopatológico com o objetivo de verificar a ocorrência de Toxoplasma gondii em suínos abatidos com e sem serviço de inspeção. Foram coletados soros de 60 suínos para a pesquisa de anticorpos anti-T. gondii pela reação de imunofluorescência indireta (RIFI). Também foram coletados fragmentos de língua, masseter e diafragma para a detecção do DNA do parasito por meio da reação em cadeia da polimerase (PCR) e análise histopatológica. A análise sorológica demonstrou que 77\% (44/60) dos suínos apresentaram anticorpos anti-T. gondii. Com relação ao PCR, 66,67\% (40/60) foram positivos para T. gondii. Dentre os tecidos avaliados, o diafragma foi o que obteve maior frequência de positividade (40\%; $24 / 60)$, seguidos de masseter (38,33\%; 23/60) e língua (33,3\%; 20/60). Alterações histopatológicas foram observadas apenas no diafragma, que apresentou infiltrado inflamatório do tipo linfohistiocitário e neutrofílico. Esses resultados não evidenciam apenas a ameaça potencial de $T$. gondii à saúde humana, mas também demonstram a dinâmica situação epidemiológica da toxoplasmose em suínos na região da cidade de São Luís, fornecendo suporte para a segurança alimentar de suínos e programas de controle de $T$. gondii no país.
\end{abstract}

Palavras-chave: Suínos, zoonoses, toxoplasmose, saúde pública. 


\section{Introduction}

Toxoplasmosis is a worldwide zoonosis caused by the obligate intracellular protozoon Toxoplasma gondii. Infection caused by $T$. gondii is widespread among homeothermic animals including birds, wild animals, domestic animals and humans (Dubey, 2009). According to Dubey (2010), domestic and wild felids are the only definitive hosts, with production and release of oocysts occurs in the feces, and thus contaminate the environment. After sporulation, these oocysts can maintain their infectivity for several months in water and soil and are responsible for infestation of intermediate hosts, including humans and other animals (Buxton et al., 2007). Pigs acquire infection by ingesting water and feed that are contaminated with oocysts from in feline feces, or transplacentally or by ingesting bradyzoites that are present in tissue cysts in intermediate hosts (rats) or other pigs in cases of cannibalism (Dubey et al., 1995; De Berardinis et al., 2017).

Studies among pigs are important because there is high production and consumption of their meat. The per capita consumption of pig meat in Brazil is $15.3 \mathrm{~kg} / \mathrm{year}$. Given that the cysts are not detectable at slaughter, this food when eaten raw or undercooked is an important route for transmission of $T$. gondii to humans. According to the United Nations Food and Agriculture Organization (FAO) and the World Health Organization (WHO), this parasite is among the top ten foodborne parasites with global impact, only behind agents such as Taenia solium, Echinococcus granulosus and Echinococcus multilocularis (FAO, 2014; ABPA, 2019).

The estimated global prevalence of infection by this important foodborne pathogen is $30 \%$ (Haq et al., 2016). In Brazil, serological studies on pigs have shown varying prevalences, with widespread distribution throughout the country, ranging from 1.32\% to 90.4\% (Cavalcante et al., 2006; Azevedo et al., 2010; Oliveira et al., 2018).

Considering the importance of this zoonosis and that the current infection status of $T$. gondii in pigs for slaughter in the state of Maranhão, Brazil, is still unclear, the objective of this study was to evaluate the occurrence rate of this parasite in pigs slaughtered and marketed for human consumption, through serological, molecular and histopathological approaches.

\section{Materials and methods}

\section{Ethics statement}

This research was approved by the Ethics Committee for Animal Experimentation (CEEA) of the State University of Maranhão (UEMA), under protocol no. 10/2017.

\section{Study area}

This is a descriptive study of the occurrence of $T$. gondii by serological and molecular techniques that was conducted between September 2017 and March 2018 in the municipality of São Luís (02 ${ }^{\circ} 31^{\prime}$ 48" S; 44 18' 10" W), the capital of the state of Maranhão, in northeastern Brazil. This location belongs to the Amazon biome, in the legal Amazon region, with a predominantly humid tropical climate (IBGE, 2020).

\section{Animals and sample collection}

Samples were selected by means of non-probabilistic convenience sampling. Sixty mixed-breed pigs (38 males and 22 females), ranging in age from 3 to 8 months, were included in this study. Of these, 41 animals were selected at slaughterhouses with inspection services and 19 animals at unofficial slaughterhouses. In the inspected slaughterhouses, the slaughter of pigs usually took place only once a week, in which a limited number of animals were slaughtered per day (ranging from 40 to 60 pigs). In this way, we collect, at the time of slaughter, blood and tissue of 6 or 7 animals a day, in 5 fields to cover the largest number of herds in the municipality.

Additionally, information only about the origin, age and sex of officially slaughtered animals (information available at the slaughterhouse) was collected. Regarding animals submitted to slaughter without inspection service in addition to the information mentioned above, it was identified that they were raised in an extensive regime, with predominantly family labor and rustic facilities for confinement of the animal.

Blood samples, about $6 \mathrm{ml}$, were collected during bleeding and were stored in tubes containing gel clotting activator to obtain serum. These were then were centrifuged at $2000 \mathrm{rpm}$ for 10 minutes to separate the serum and stored in microtubes at $-20^{\circ} \mathrm{C}$ until the time of the serological tests. Immediately after slaughter, two fragments 
of $50 \mathrm{~g}$ from the tongue, diaphragm and masseter of each animal were collected. One was stored at $-20{ }^{\circ} \mathrm{C}$ until molecular testing; the other was fixed in $10 \%$ buffered formalin solution for histopathological analysis.

\section{Serological test}

Serum samples were tested using the immunofluorescence antibody test (IFAT) for the detection of IgG anti-T. gondii, using the commercial Imunoteste Toxopasma kit (RIFI), adapted from cattle (Immunodot ${ }^{\circledR}$ ). The conjugate used in the reactions was anti-pig IgG (Sigma-Aldrich ${ }^{\circledR}$ St. Louis, Missouri, United States), and those samples with cutoff titers of 1:40 were considered positive according to the manufacturer's instructions (Immunodot ${ }^{\circledR}$ ). Positive and negative control sera were included on all slides.

\section{DNA extraction and PCR}

DNA extraction and purification of tissue samples were performed using the Wizard Genomic DNA purification kit (Promega ${ }^{\circledR}$ ), as instructed by the manufacturer. The concentration and quality of the extracted DNA were determined by means of spectrophotometry.

The PCR was carried out using the primers Tox4 (CGCTGCAGG GAGGAAGACGAAAGTTG) and Tox5 (CGCTGCAGA CACAGTGCATCTGGATT), as described by Homan et al. (2000), which amplified a fragment of 529 bp of $T$. gondii DNA. Each reaction had a total volume of $12.5 \mu \mathrm{L}$, as follows: $6.25 \mu \mathrm{L}$ of PCR Master Mix Promega ${ }^{\circledR}$ (Taq polymerase, dNTPs, $\mathrm{MgCl}_{2}$ and buffer); $0.5 \mu \mathrm{L}$ of each primer (10 pmol); $4.25 \mu \mathrm{L}$ of DNAse and RNAse-free water and $1 \mu \mathrm{L}$ of extracted DNA. The thermocycler conditions were: $7 \mathrm{~min}$ at $94^{\circ} \mathrm{C}$ for denaturation, followed by 34 cycles of $1 \mathrm{~min}$ at $94{ }^{\circ} \mathrm{C}$ for denaturation, 1 minute at $55^{\circ} \mathrm{C}$ for annealing and 1 min at $72{ }^{\circ} \mathrm{C}$ for extension, followed by a final extension of 10 minutes at $72^{\circ} \mathrm{C}$.

The PCR products were subjected to electrophoresis on 1.5\% agarose gel, stained with SYBR Safe (Invitrogen ${ }^{\circledR}$ ), and using a molecular weight marker (1 Kb DNA ladder, Promega $\left.{ }^{\circledR}\right)$. After this step, the gel was analyzed and photographed in photodocumentation system.

\section{Histopathology}

Tissue fragments were fixed in $10 \%$ buffered formalin and were processed to prepare histological slides, using the methodology described by Luna (1968). The material was cut into sections of thickness five micrometers $(5 \mu \mathrm{m})$ and these were stained using the hematoxylin and eosin (HE) technique, as described by Prophet et al. (1992). The slides produced were then analyzed to detect any presence of tissue forms of the parasite and any histopathological changes, under a microscope using a 40x objective lens.

\section{Statistical analysis}

The date on frequency of positivity among the animals were tabulated and statistically analyzed by means of the relative and absolute frequency distribution, and were distributed in contingency tables. Initially, a chi-square test $\left(\chi^{2}\right)$ was performed on independent samples to evaluate possible associations between the test used (IFAT) and positivity for $T$. gondii. Univariate analysis was performed considering the animal characteristics (origin and sex), using the chi-square test $\left(\chi^{2}\right)$. The analyses were performed using the Epi Info ${ }^{\mathrm{TM}}$ software, version 7.2.4. All statistical analyses were performed considering a minimum significance level of $5 \%(p \leq 0.05)$.

\section{Results}

In total, antibodies against $T$. gondii were found in 77\% (44/60) of the pigs analyzed. Among the unofficially slaughtered pig population, 63.16\% (12/19) were seroreactive and among those slaughtered in an establishment with presence of the inspection service, 78.05\% (32/41). Regarding sex, 73.68\% (32/38) of the males were positive, while $72.73 \%$ (16/22) of the females were positive (Table 1).

The results from the statistical analysis showed that there were no significant associations between the variables studied $(p>0.05)$, although the frequency of infection among the pigs from slaughterhouses with presence of the inspection service was higher than among those from unofficial slaughterhouses. 
Table 1. Frequencies of infection in pigs, from IFAT, according to origin and sex. Univariate analysis on associations between variables and positivity using the chi-square test. There were no statistically significant differences $(p>0.05)$ between the variables evaluated.

\begin{tabular}{|c|c|c|c|c|c|c|}
\hline \multirow{2}{*}{\multicolumn{2}{|c|}{ Feature }} & \multicolumn{5}{|c|}{ IFAT } \\
\hline & & No. positive & No. negative & Total & $\%$ & $\mathbf{p}$ \\
\hline \multirow[t]{2}{*}{ Provenance } & Insp. & 32 & 9 & 41 & 78.05 & $0.8092^{\text {ns }}$ \\
\hline & Not insp. & 12 & 7 & 19 & 63.16 & \\
\hline \multirow[t]{2}{*}{ Sex } & Male & 28 & 10 & 38 & 73.67 & 0.9361 ns \\
\hline & Female & 16 & 6 & 22 & 72.73 & \\
\hline \multicolumn{2}{|c|}{ Total number of animals tested } & 44 & 16 & 60 & 77 & \\
\hline
\end{tabular}

NS = no significant association $(p>0.05)$.

Table 2. Percentages and absolute frequencies of positivity for T. gondii from conventional PCR in diaphragm, masseter and tongue tissues. There were no statistically significant differences $(p>0.05)$ between the tissues evaluated.

\begin{tabular}{ccccc}
\hline \multirow{2}{*}{ Tissue } & \multicolumn{3}{c}{ PCR } \\
\cline { 2 - 5 } & No. positive & No. negative & \% & $\mathbf{0 . 7 3 4 1}$ \\
\hline Diaphragm & 24 & 36 & 40 & 38.33 \\
Masseter & 23 & 37 & 33.3 \\
Tongue & 20 & 40 & 66.97 \\
Total number of & 40 & 20 & & \\
animals tested & & & \\
\hline
\end{tabular}

Direct PCR on tissues from the pigs showed evidence of $T$. gondii DNA in $66.67 \%$ (40/60), considering at least one positive tissue sample per animal evaluated. The data on the frequency of tissue positivity are summarized in Table 2. The statistical analysis on the data showed that there were no statistically significant differences $(p \leq 0.05)$ between the tissues evaluated.

Among the tissues analyzed histopathologically, in the diaphragm fragment of one animal it was possible to identify multifocal areas of myositis, characterized by a lymphohistiocytic and neutrophilic inflammatory infiltrate associated with hyperemia, hemorrhage and necrosis (Figure 1a, b). No intralesional organisms suggestive of T. gondii were observed in the areas of these injuries.

\section{Discussion}

This study presents an important contribution about toxoplasmosis, through providing new data on infection in pigs in the state of Maranhão. To the best of our knowledge, this was the first study to report on the circulation of $T$. gondii in pigs in this area. These data are of public health relevance, because pigs act as reservoirs for this protozoan and consumption of pig meat under these conditions represents a risk to human health, as already shown in previous studies (Dubey, 2009; Vergara et al., 2018; Miura et al., 2019; Oliveira et al., 2018; Santos et al., 2019). In addition, investigations on occurrences of $T$. gondii in pigs form an important step within surveillance and control of foodborne toxoplasmosis.

In this context, serological surveys are important diagnostic tools for surveillance of pathogens such as T. gondii. They are considered to provide conclusive data for adequate surveillance of toxoplasmosis (Dubey, 2009; Tialla et al., 2019).

In this study, we found that the overall infection rate was $77 \%$, which was higher to the prevalences reported Africa (49.2\%), Italy (51.7\%) and China (13.8\%) (Pipia et al., 2018; Tialla et al., 2019; Zhang et al., 2020). In the Brazilian scenario, the detection of antibodies against $T$. gondii varies widely between different regions. Studies conducted in 


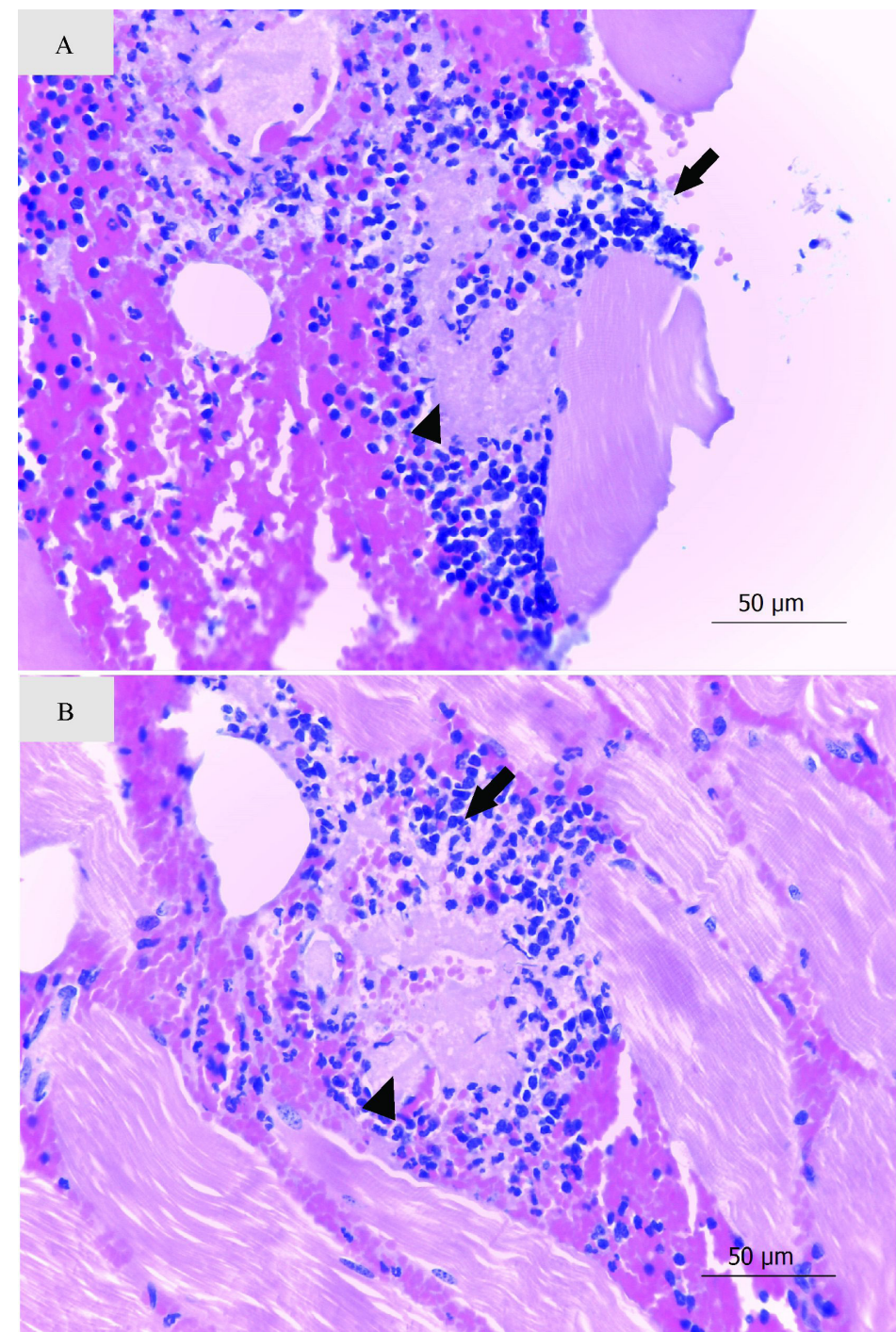

Figure 1. Representative photomicrograph from histopathological analysis on pig tissues. (A) and (B), areas of hyperemia and hemorrhage associated with moderate lymphohistiocytic and neutrophilic inflammatory infiltrate (arrows), associated with necrosis (arrowhead), $\mathrm{HE}, 40 \mathrm{x}$.

Paraíba, Rio Grande do Norte and Paraná reported rates of $12.4 \%, 40.7 \%$ and $6.5 \%$, respectively. These variations maybe related to some factors such as the serological test applied, the animal husbandry system, among other conditions such as climate and geographic location (Albuquerque et al., 2011; Bacci et al., 2015; Zhang et al., 2020).

The results from the statistical analysis showed that there was no significant association in relation to the variable of sex $(p \leq 0.05)$. This differed from previous results found in Burkina Faso and Nigeria (Africa) and Paraná (Brazil) (Moura et al., 2007; Onyiche \& Ademola, 2015; Tialla et al., 2019), where a significant association between sex and the presence of anti- $T$. gondii antibodies was found, such that females showed significantly higher prevalence. Some authors have claimed that female sex is a risk factor for toxoplasmosis due to hormonal, physiological and management differences (van der Puije et al., 2000).

Regarding the origin of the animals, the present study showed that there was high serological frequency of infection among pigs that were subjected to unofficial slaughter, although there was no statistical difference between the groups analyzed. It is important note, in relation to unofficial or "backyard" slaughter, that some dubious situations were observed. These included the following: pigs that had been extensively reared together with other animals that are susceptible to infection, including birds; slaughter carried out in inappropriate places and under poor sanitary conditions, without inspection and without compliance with animal welfare standards; 
and absence of control measures against rodents, which may act as a parasite reservoir for pigs and other hosts such as felids (data not shown). Although no detailed analysis of risk factors associated with parasite infection was performed in this study, previous studies have shown that such situations may predispose to $T$. gondii infection in pigs (Millar et al., 2008; Dubey, 2009). This allows us to suggest that the situations observed may have influenced the infection rate found.

A high percentage of positive animals was observed among those subjected to slaughter under official inspection, similar to what was observed among those slaughtered unofficially. Therefore, it can be suggested that these animals probably came from herds where management and sanitation care were inefficient. Thus, even though the animals were subjected to different ways of slaughter, it is possible that they had been reared under conditions presenting similar risk factors. Previous studies have shown the importance of proper management on pig farms in relation to T. gondii infection (Samico-Fernandes et al., 2017; Gazzonis et al., 2018). Dubey (2009) pointed out that the determining factor in infection among pigs does not come from the rearing system itself, but from the exposure of these animals to oocysts and/or rodents in the environment.

Occurrences of this parasite detected through molecular techniques in epidemiological studies are increasing in Brazil, as demonstrated in Bahia (10\%) and Rio Grande do Sul (34\% and 66\%) (Bezerra et al., 2012; Belfort-Neto et al., 2007). It was possible to detect parasite DNA in all the tissues analyzed in the present study (tongue, diaphragm and masseter). Dubey et al. (1996) pointed out that after infection the parasite can be found in almost all swine tissues, especially in organs such as the brain and the skeletal and cardiac muscles. The same authors showed that muscle tissues presented low quantities of parasites. However, bioassays performed in mice have demonstrated that even in small numbers, viable cysts are capable of causing persistent infections.

Several researchers have used muscle tissue to detect $T$. gondii and obtained good results in their research (Belfort-Neto et al., 2007; Hernández-Cortazar et al., 2016; Kuruca et al., 2017). Based on this presupposition and that our intention was to carry out the diagnosis of the parasite in tissues that could be easily obtained and tested, we chose these tissues. In addition, during sample collection, we had access only to collect muscle tissue, without access to brain fragments.

In this study, the rate of detection of infection by means of PCR was very similar to what was found using IFAT. Although other studies have shown that this technique may be less sensitive than bioassays or other serological tests, it is important to consider certain factors that may lead to these differences. These would include the experimental group (naturally or experimentally infected animals), the target genes used in PCR and the distribution of the parasite among the tissues analyzed (Reischl et al., 2003; Hill et al., 2006; Tsutsui et al., 2007; Bacci et al., 2015; Franco-Hernandez et al., 2016).

In the present study, the frequency of histopathological changes was considered low, as was also reported in previous studies that shows the difficulty in detecting parasites using the histological technique (Bezerra et al., 2012; Miranda et al., 2015; Samico-Fernandes et al., 2017). This situation, as suggested by Dubey (2009), can be attributed to factors such as the parasite distribution itself, which is not homogeneous, and the low quantities of cysts in muscle tissues. It is also important to emphasize that the sensitivity rate of the histopathological technique is lower among naturally infected animals (Dubey \& Beattie, 1988), as were the animals of the present study.

Despite the positivity of the animals of the present study according to PCR, few lesions were found in only a fragment of the diaphragm, however, as no cysts or bradyzoites of $T$. gondii were found in these areas, we cannot say that these lesions originated directly by the action of the parasite, but it is noteworthy that this tissue was positive by PCR. This primary study serves as a warning for T. gondii infection in pigs sold in the city of São Luís, a fact that so far has not been demonstrated by previous research and demonstrates the concern with the sanitary situation of the pigs. Certainly, our study will contribute to further research being carried out in this location, including a broader epidemiological study.

\section{Conclusion}

These results indicate the occurrence of Toxoplasma gondii in slaughtered pigs sold for human consumption. This study provides strong support for implementation of prevention and control measures against human infections by $T$. gondii originating from pigs slaughtered in the city of São Luis, Maranhão. 


\section{Acknowledgements}

The authors wish to thank the Immunoparasitology Laboratory of UNESP, in Jaboticabal, for the support and improvement of this work. We would like to thank the Parasitology Laboratory of UEMA for its support. We also thank FAPEMA and CAPES for the financial support.

\section{References}

Albuquerque GR, Munhoz AD, Teixeira M, Flausino W, Medeiros SM, Lopes CWG. Risk factors associated with Toxoplasma gondii infection in dairy cattle, State of Rio de Janeiro. Pesq Vet Bras 2011; 31(4): 287-290. http://dx.doi.org/10.1590/S0100736X2011000400003.

Associação Brasileira de Proteína Animal - ABPA. Relatório Anual de Atividades [online]. 2019 [cited 2020 June 17]. Available from: http://abpa-br.org/abpa-lanca-relatorio-anual-2020/

Azevedo SS, Pena HFJ, Alves CJ, Guimarães AAM Fo, Oliveira RM, Maksimov P, et al. Prevalence of anti-Toxoplasma gondii and anti-Neospora caninum antibodies in swine from northeastern Brazil. Rev Bras Parasitol Vet 2010; 19(2): 80-84. http://dx.doi. org/10.1590/S1984-29612010000200002. PMid:20624342.

Bacci C, Vismarra A, Mangia C, Bonardi S, Bruini I, Genchi M, et al. Detection of Toxoplasma gondii in free-range, organic pigs in Italy using serological and molecular methods. Int J Food Microbio/ 2015; 202: 54-56. http://dx.doi.org/10.1016/j.ijfoodmicro.2015.03.002. PMid:25771511.

Belfort-Neto R, Nussenblatt V, Rizzo L, Muccioli C, Silveira C, Nussenblatt R, et al. High prevalence of unusual genotypes of Toxoplasma gondii infection in pork meat samples from Erechim, Southern Brazil. An Acad Bras Cienc 2007; 79(1): 111-114. http:// dx.doi.org/10.1590/S0001-37652007000100013. PMid:17401480.

Bezerra RA, Carvalho FS, Guimarães LA, Rocha DS, Silva FL, Wenceslau AA, et al. Comparison of methods for detection of Toxoplasma gondii in tissues of naturally exposed pigs. Parasitol Res 2012; 110(2): 509-514. http://dx.doi.org/10.1007/s00436011-2514-1. PMid:21739310.

Buxton D, Maley SW, Wright SE, Rodger S, Bartley P, Innes EA. Toxoplasma gondii and ovine toxoplasmosis: new aspects of an old story. Vet Parasitol 2007; 149(1-2): 25-28. http://dx.doi.org/10.1016/j.vetpar.2007.07.003. PMid:17686585.

Cavalcante GT, Aguiar DM, Chiebao D, Dubey JP, Ruiz VLA, Dias RA, et al. Seroprevalence of Toxoplasma gondii antibodies in cats and pigs from rural western Amazon, Brasil.J Parasito/ 2006; 92(4): 863-864. http://dx.doi.org/10.1645/GE-830R.1. PMid:16995406.

De Berardinis A, Paludi D, Pennisi L, Vergara A. Toxoplasma gondii, a foodborne pathogen in the swine production chain from a European perspective. Foodborne Pathog Dis 2017; 14(11): 637-648. http://dx.doi.org/10.1089/fpd.2017.2305. PMid:28759251.

Dubey JP, Beattie CP. Toxoplasmosis of animals and man. Boca Raton, FL: CRC Press; 1988.

Dubey JP, Lunney JK, Shen SK, Kwok OCH, Ashford DA, Thulliez P. Infectivity of Low Numbers of Toxoplasma gondii Oocysts to Pigs. J Parasitol 1996; 82(3): 438-443. http://dx.doi.org/10.2307/3284082. PMid:8636849.

Dubey JP, Weigel RM, Siegel AM, Thulliez P, Kitron UD, Mitchell MA, et al. Sources and reservoirs of Toxoplasma gondii infection on 47 swine farms in Illinois. J Parasitol 1995; 81(5): 723-729. http://dx.doi.org/10.2307/3283961. PMid:7472862.

DubeyJP. Toxoplasmosis in pigs-the last 20 years. Vet Parasito/2009; 164(2-4): 89-103. http://dx.doi.org/10.1016/j.vetpar.2009.05.018. PMid:19559531.

Dubey JP. Toxoplasmosis of animals and humans. 2nd ed. Beltsville, Maryland: CRC Press; 2010.

Food and Agriculture Organization of the United Nations - FAO. World Health Organization - WHO. Multicriteria-based ranking for risk management of foodborne parasites [online] 2014 [cited 2020 June 17]. Available from: http://www.fao.org/3/a-i3649e.pdf

Franco-Hernandez EN, Acosta A, Cortés-Vecino J, Gómez-Marín JE. Survey for Toxoplasma gondii by PCR detection in meat for human consumption in Colombia. Parasitol Res 2016; 115(2): 691-695. http://dx.doi.org/10.1007/s00436-015-4790-7. PMid:26481490.

Gazzonis AL, Marangi M, Villa L, Ragona ME, Olivieri E, Zanzani SA, et al. Toxoplasma gondii infection and biosecurity levels in fattening pigs and sows: serological and molecular epidemiology in the intensive pig industry (Lombardy, Northern Italy). Parasitol Res 2018; 117(2): 539-546. http://dx.doi.org/10.1007/s00436-017-5736-z. PMid:29299685.

Haq SZ, Abushahama MS, Gerwash O, Hughes JM, Wright EA, Elmahaishi MS, et al. High frequency detection of Toxoplasma gondii DNA in human neonatal tissue from Libya. Trans R Soc Trop Med Hyg 2016; 110(9): 551-557. http://dx.doi.org/10.1093/trstmh/ trw064. PMid:27794096.

Hernández-Cortazar IB, Acosta-Viana KY, Guzmán-Marin E, Ortega-Pacheco A, Torres-Acosta JFJ, Jimenez-Coello M. Presence of Toxoplasma gondii in pork intended for human consumption in tropical southern Mexico. Foodborne Pathog Dis 2016; 13(12): 695-699. http://dx.doi.org/10.1089/fpd.2016.2165. PMid:27661133. 
Hill DE, Chirukandoth S, Dubey JP, LunneyJK, Gamble HR. Comparison of detection methods for Toxoplasma gondii in naturally and experimentally infected swine. Vet Parasito/ 2006; 141(1-2): 9-17. http://dx.doi.org/10.1016/j.vetpar.2006.05.008. PMid:16815636.

Homan WL, Vercammen M, De Braekeleer J, Verschueren H. Identification of a 200-to 300-fold repetitive 529 bp DNA fragment in Toxoplasma gondii, and its use for diagnostic and quantitative PCR. Int J Parasito/ 2000; 30(1): 69-75. http://dx.doi.org/10.1016/ S0020-7519(99)00170-8. PMid:10675747.

Instituto Brasileiro de Geografia e Estatística - IBGE. Cidades, São Luís, Maranhão, Brasil [online]. 2020 [cited 2020 May 10]. Available from: https://cidades.ibge.gov.br/brasil/ma/sao-luis/panorama

Kuruca L, Klun I, Uzelac A, Nikolić A, Bobić B, Simin S, et al. Detection of Toxoplasma gondii in naturally infected domestic pigs in Northern Serbia. Parasitol Res 2017; 116(11): 3117-3123. http://dx.doi.org/10.1007/s00436-017-5623-7. PMid:28956155.

Luna LG. Manual of histologic staining methods of the Armed Forces Institute of Pathology. New York: McGraw-Hill; 1968.

Millar PR, Daguer H, Vicente RT, Costa TD, Sobreiro LG, Amendoeira MRR. Toxoplasma gondii: estudo soro-epidemiológico de suínos da região Sudoeste do Estado do Paraná. Pesq Vet Bras 2008; 28(1): 15-18. http://dx.doi.org/10.1590/S0100-736X2008000100002.

Miranda FJB, Souza DB, Frazão-Teixeira E, Oliveira FC, Melo JC, Mariano CMA, et al. Experimental infection with the Toxoplasma gondii ME-49 strain in the Brazilian BR-1 mini pig is a suitable animal model for human toxoplasmosis. Mem Inst Oswaldo Cruz 2015; 110(1): 95-100. http://dx.doi.org/10.1590/0074-02760140318. PMid:25742268.

Miura AC, de Barros LD, Ferreira FP, Ferreira JM No, Sicupira Franco PML, Su C, et al. Genotyping of Toxoplasma gondii isolated from pigs for human consumption. Parasitol Res 2019; 118(5): 1593-1599. http://dx.doi.org/10.1007/s00436-019-06274-1. PMid:30852640.

Moura AB, Osaki SC, Zulpo DL, Marana ERM. Ocorrência de anticorpos contra Toxoplasma gondii em suínos e ovinos abatidos no Município de Guarapuava, PR, Brasil. Rev Bras Parasitol Vet 2007; 16(1): 54-56. PMid:17588324.

Oliveira GC, Almeida HMS, Sartori RS, Rossi GAM, de Oliveira LG, Langoni H. Prevalence of Toxoplasma gondii infections in swine of non-tecnified rearing farms of the northeastern region of the state of São Paulo, Brazil and associated risk factors. Parasite Epidemiol Control 2018; 4: e00080. http://dx.doi.org/10.1016/j.parepi.2018.e00080. PMid:30662965.

Onyiche TE, Ademola IO. Seroprevalence of anti-Toxoplasma gondii antibodies in cattle and pigs in Ibadan, Nigeria. J Parasit Dis 2015; 39(2): 309-314. http://dx.doi.org/10.1007/s12639-013-0350-1. PMid:26064025.

Pipia AP, Varcasia A, Dessì G, Panzalis R, Gai C, Nonnis F, et al. Seroepidemiological and biomolecular survey on Toxoplasma gondii infection on organic pig farms. Parasitol Res 2018; 117(5): 1637-1641. http://dx.doi.org/10.1007/s00436-018-5823-9. PMid:29500767.

Prophet EB, Mills B, Hall J, Achstetter VA, Allen TC. Fixation; tissue processing; dehydration, clearing, and infiltration; specimen orientation; embedding; microtomy; hematoxylin and eosin, and mounting media. Washington, DC: ARP Press, AFIP; 1992.

Reischl U, Bretagne S, Krüger D, Ernault P, Costa JM. Comparison of two DNA targets for the diagnosis of Toxoplasmosis by real-time PCR using fluorescence resonance energy transfer hybridization probes. BMC Infect Dis 2003; 3: 7. http://dx.doi. org/10.1186/1471-2334-3-7. PMid:12729464.

Samico-Fernandes EFT, Samico-Fernandes MFT, de Albuquerque PPF, de Almeida JC, de Souza Santos A, da Rocha Mota A, et al. Toxoplasma gondii in backyard pigs: seroepidemiology and mouse bioassay. Acta Parasitol 2017; 62(2): 466-470. http://dx.doi. org/10.1515/ap-2017-0054. PMid:28426411.

Santos IMC, Leite AI, Furquim MEC, Zanatto DCS, Fernandes SJ, Silva GCP, et al. Frequency of antibodies and risk factors associated with Toxoplasma gondii infection in backyard pig production in the city of Mossoró, state of Rio Grande do Norte, Brazil. Rev Bras Parasitol Vet 2019; 28(3): 508-513. http://dx.doi.org/10.1590/s1984-29612019036. PMid:31188949.

Tialla D, Dahourou LD, Gbati OB. Seroprevalence and factors associated with bovine and swine toxoplasmosis in Bobo-Dioulasso, Burkina Faso. Vet World 2019; 12(10): 1519-1523. http://dx.doi.org/10.14202/vetworld.2019.1519-1523. PMid:31849410.

Tsutsui VS, Freire RL, Garcia JL, Gennari SM, Vieira DP, Marana ERM, et al. Detection of Toxoplasma gondii by PCR and mouse bioassay in commercial cuts of pork from experimentally infected pigs. Arq Bras Med Vet Zootec 2007; 59(1): 30-34. http://dx.doi. org/10.1590/S0102-09352007000100006.

van der Puije WNA, Bosompem KM, Canacoo EA, Wastling JM, Akanmori BD. The prevalence of anti- Toxoplasma gondii antibodies in Ghanaian sheep and goats. Acta Trop 2000; 76(1): 21-26. http://dx.doi.org/10.1016/S0001-706X(00)00084-X. PMid:10913761.

Vergara A, Marangi M, Caradonna T, Pennisi L, Paludi D, Papini R, et al. Toxoplasma gondii lineages circulating in slaughtered industrial pigs and potential risk for consumers. J Food Prot 2018; 81(8): 1373-1378. http://dx.doi.org/10.4315/0362-028X.JFP17-496. PMid:30019961.

Zhang Y, Gong H, Mi R, Huang Y, Han X, Xia L, et al. Seroprevalence of Toxoplasma gondii infection in slaughter pigs in Shanghai, China. Parasitol Int 2020; 76: 102094. http://dx.doi.org/10.1016/j.parint.2020.102094. PMid:32109578. 